\title{
Synthesis and cyto-genotoxicity evaluation of graphene on mice spermatogonial stem cells
}

\author{
Ehsan Hashemi ${ }^{1,2}$, Omid Akhavan ${ }^{3,4}$, Mehdi Shamsara ${ }^{1,2}$, Morteza Daliri² $^{*}$, Mojtaba Dashtizad $^{2}$, \\ Abbas Farmany ${ }^{5 *}$ \\ ${ }^{1}$ National Research Center for Transgenic Mouse, National Institute of Genetic Engineering and \\ Biotechnology, P.O. Box 14965-161, Tehran, Iran \\ ${ }^{2}$ Animal Biotechnology Division, National Institute of Genetic Engineering and Biotechnology, \\ P.O. Box 14965-161, Tehran, Iran \\ ${ }^{3}$ Department of Physics, Sharif University of Technology, P.O. Box 11155-9161, Tehran, Iran \\ ${ }^{4}$ Institute for Nanoscience and Nanotechnology, Sharif University of Technology, P.O. Box \\ 14588-89694, Tehran, Iran \\ ${ }^{5}$ Departments of Chemistry Hamedan Branch, Islamic Azad University, Hamedan, Iran
}

\begin{abstract}
The present study analyzed the dose-dependent cyto- and genotoxicity of graphene oxide and reduced graphene oxide on spermatogonial stem cells (SSCs) for the first time. The results showed that graphene oxide significantly increased oxidative stress at concentrations of 100 and $400 \mu \mathrm{g} / \mathrm{ml}$, while low concentrations did not have a significant effect. In addition, according to the MTT assay, the cell number decreased in high-concentration (100 and $400 \mu \mathrm{g} / \mathrm{ml})$ graphene oxide-treated samples compared to untreated cells. However, a reduced graphene-treated sample demonstrated a significant increase in cell number. Moreover, microscopic analysis found high concentrations of graphene nanosheets in cell culture medium that reduced the number of colonies and colony forming cells. We conclude that a high concentration of graphene can be toxic to SSCs. However, such toxicity can be reduced by the surface modification of graphene nanomaterials.
\end{abstract}

Keywords: oxidative stress, graphene, spermatogonial stem cells, cytotoxicity, genotoxicity 


\section{Introduction}

Nanomaterials have been recently applied in fields such as medicine, agriculture, and industry, as well as the environment. Regarding medicine, different types of nanoparticles have been used in cancer therapy, wound healing, infectious diseases, and drug delivery (Feng\& Liu, 2011; Jain 2010; Maynard et al., 2006; Maynard, 2011). Graphene is a new 2-dimensional nanomaterial with special properties, including a large surface area, high electrical and thermal conductivity, and increased mechanical properties and biocompatibility. Additionally, large scale production of graphene is low in cost. These properties have caused graphene to be an applicable material in electronics and medicine (Li et al., 2008; Sun et al., 2008). Consequently, graphene nanoparticles are currently employed in drug delivery, photo-thermal cancer therapy, bio-sensing, biocompatible scaffolds, bio-imaging, and anti-microbial components (Zhang et al., 2010; Yang et al., 2011; Zhu et al., 2012; Feng, Zhang\& Liu 2011; Bao et al., 2011; Zhang et al., 2011; Artiles, Rout\& Fisher, 2011; Zhu et al., 2011; Heidarimoghadam et al., 2016; Shen et al., 2012). Increasing interest in the use of graphene nanoparticles might increase the risk of human exposure to such materials in the environment. Although research on the technical and biomedical applications of graphene, graphene oxide and graphene derivative nanomaterials is expanding rapidly, there has been insufficient research regarding the possible effects of biohazardous graphene nanomaterial on biological systems and their intrinsic toxicity (Sanchez et al. 2012). Accordingly, the identification of graphene toxicity could result in the generation of safer nanoparticles by manipulating factors, such as size and dose. A number of studies have examined the toxicity of graphene nanoparticles on cells. The mechanisms that underlie the cytotoxic effects lead to the impairment of mitochondrial activity (Sasidharan et al., 2011; Akhavan\& Ghaderi 2010), plasma membrane damage (Sasidharan et al., 2011; Akhavan\& Ghaderi 2010; Zhang et al., 2010), induction of oxidative stress (Zhang et al., 2010; Yue et al., 
2012; Li et al., 2012; Chang et al., 2010), DNA damage (Akhavan, Ghaderi\& Akhavan, 2012); and apoptotic and/or necrotic cell death (Sasidharan et al., 2011; Zhang et al., 2010; Li et al., 2012; Yuan et al., 2012).

Most of the cytotoxic studies have been performed on somatic cells, not spermatogonial stem cells (SSCs) (Akhavan et al., 2012; Akhavan, Ghaderi\& Emamy, 2012; Yang et al. 2010; Hashemi, et al., 2014). SSCs are unique cell populations that can self-renew and differentiate into germ cells. The biomedical applications of graphene may not be realized unless the potential toxicity of this nanomaterial to humans and other biological systems is thoroughly ascertained. Therefore, the present study explores the cyto- and genotoxicity of graphene nanoparticles on SSCs. The MTT assay was utilized to study the viability of SSCs treated with graphene nanoparticles. Dose-dependent cyto-genotoxicity of graphene nanoparticles was reported for the first time. The comet assay was also employed to study DNA damage and chromosomal aberrations. In addition, the oxidant-sensitive dye assay was used to monitor the level of reactive oxygen species (ROS).

\section{Material and methods}

\section{Synthesis of Graphene Oxide}

The modified Hummers' method was applied to synthesize graphite oxide (GO) from natural graphite powder (particle diameter $\leq 40 \mu \mathrm{m}$, Sigma-Aldrich) (Hummers\& Offeman, 1958; Kovtyukhova et al., 1999). Typically, $0.5 \mathrm{~g}$ of graphite powder was added into $\mathrm{H}_{2} \mathrm{SO}_{4}$ at $80{ }^{\circ} \mathrm{C}$ for $5 \mathrm{~h}$. Then, $0.5 \mathrm{~g}$ of $\mathrm{NaNO}_{3}$ was added and the mixture was stirred in an ice bath for 10 minutes. Next, $3.0 \mathrm{~g}$ of $\mathrm{KMnO}_{4}$ was slowly added and mixed for an additional $2 \mathrm{~h}$. Once the $\mathrm{KMnO}_{4}$ was dissolved, the mixture was cooled to room temperature in a $35{ }^{\circ} \mathrm{C}$ water bath. The 
suspension was diluted by adding $40 \mathrm{ml}$ of deionized (DI) water. During the dilution, the temperature was fixed at $<60{ }^{\circ} \mathrm{C}$. Then, $3 \mathrm{ml}$ of $\mathrm{H}_{2} \mathrm{O}_{2}(30 \%$, diluted in $100 \mathrm{ml}$ DI water) was added to the suspension. The residual acids and salts in the suspension were removed by a membrane filter ( $47 \mathrm{~mm}$ in diameter, $0.2-\mu \mathrm{m}$ pore size, Whatman). The filtered graphite oxide material was dispersed in DI water to achieve an aqueous suspension with a yellowish-brown color. After centrifugation of the aqueous suspension (Eppendorf 5702 centrifuge, $10 \mathrm{~cm}$ rotor radius), the GO suspension was obtained after sonication of the pellet.

To obtain reduced $\mathrm{GO}$ ( $\mathrm{rGO}$ ), the $\mathrm{pH}$ of the $\mathrm{GO}$ suspension was adjusted to $~ 9.0$ using an ammonia solution. Then, $100 \mu 1$ of a hydrazine solution (35\%) was added to the suspension while stirring. Next, the suspension was refluxed at $90{ }^{\circ} \mathrm{C}$ for $3 \mathrm{~h}$ in an oil bath. The prepared rGO suspension was centrifuged, filtered and resuspended in DI water.

\section{Material characterization}

The surface topography of the graphene sheets was examined using atomic force microscopy (AFM, Digital Instruments NanoScope V) in tapping mode. For AFM analysis, GO samples were prepared by drop-casting a diluted suspension $(\sim 0.01 \mathrm{mg} / \mathrm{ml})$ onto a cleaned $\mathrm{Si}(100)$ substrate. To investigate the chemical states of the GO and rGO sheets, X-ray photoelectron spectroscopy (XPS) was used. The data were acquired through a hemispherical analyzer equipped with an $\mathrm{Al} \mathrm{K} \alpha \mathrm{X}$-ray source $(\mathrm{h} v=1486.6 \mathrm{eV})$ operating at a vacuum greater than $10-7$ Pa. For further analyses, the XPS peaks were deconvoluted using Gaussian components after a Shirley background subtraction. The quantitative elemental compositions were obtained using the peak area ratio of the XPS core levels. Raman spectroscopy was performed at room temperature using a HR-800 Jobin-Yvon system supplied by a 532-nm Nd-YAG excitation 
source. The samples used for XPS and Raman spectroscopy were prepared by casting a graphene suspension onto a Si substrate and removing the solvent at $20^{\circ} \mathrm{C}$ in air for $30 \mathrm{~min}$.

\section{Isolation of spermatogonial stem cells}

One-week-old BALB/c inbred mice were anesthetized and sacrificed. Testicles were removed and placed in phosphate buffer saline (PBS) containing antibiotics. Excess tissue was removed, and the samples were washed with PBS. The testicles were chopped with a surgical blade in an enzymatic digestion mixture containing hyaluronidase, DNaseI and collagenase (Guan et al., 2009). Next, the separated cells were co-cultured with mouse fibroblast cells in DMEM containing $20 \%$ fetal bovine serum (FBS) with $50 \mathrm{IU} / \mathrm{ml}$ penicillin and $50 \mu \mathrm{g} / \mathrm{ml}$ streptomycin. Cells were observed for colony formation.

\section{Treatment of SSCs with graphene nanoparticles}

Treatment of the SSCs was performed by adding GO/rGO nanoparticles to the cultured cell medium to a final concentration of $1,10,100$ and $400 \mu \mathrm{g} / \mathrm{ml}$. An untreated culture was used as the control. Microscopic changes of the SSCs after treatment with nanoparticles were visualized using an inverted microscope (Nikon).

\section{MTT assay}

The viability of graphene nanoparticle-treated SSCs was assayed by the MTT test. The cells were briefly cultured in a 96-well plate and incubated for $3 \mathrm{~h}$ with MTT solution. DMSO was added to the wells to solubilize formazan particles, and the absorbance was read at $580 \mathrm{~nm}$ using an ELISA reader (Microplate reader labsystem multiscan).

\section{ROS assay in spermatogonia}


In the treated cells, the amount of ROS was measured using 2',7'-dichlorofluorescin diacetate (DCFH-DA) (Sigma Co.). After treatment, the cells were incubated at $37{ }^{\circ} \mathrm{C}$ and $5 \% \mathrm{CO}_{2}$ for 30 60 min with $10 \mathrm{mM}$ DCFH-DA. The cells were enzymatically detached by trypsin and washed three times with PBS. The resulting cell suspension was centrifuged for 5 minutes at 1000 RPM. The conversion rate of DCFH to dichlorofluorescein (DCF) was measured using a fluorescence spectrophotometer with a 480-nm excitation and 520-nm emission wavelengths.

\section{Membrane integrity}

Membrane integrity was tested by acridine orange staining to observe apoptotic morphological changes. The GO-treated SSCs were incubated with $100 \mu \mathrm{g} / \mathrm{ml}$ acridine orange dye for $30 \mathrm{~min}$ in a $\mathrm{CO}_{2}$ incubator. After washing with PBS three times, the SSCs were monitored at 200x magnification using a fluorescent microscope (Nikon).

\section{Comet assay}

DNA damage in the treated SSCs was investigated using a comet assay as previously described by Tice et al. (2000). Frosted slides were dipped in molten agarose and dried at $50{ }^{\circ} \mathrm{C}$. Cells were embedded in slides coated with double layers of agarose. The slides were then immersed in a lysis solution containing $\mathrm{NaCl}(2.5 \mathrm{M})$, EDTA $(100 \mathrm{mM}), \mathrm{N}$-lauroylsarcosine $(1 \%)$ and trizma $(10 \mathrm{mM})$ at a $\mathrm{pH}$ of 10 for $1 \mathrm{~h}$. Triton $\mathrm{X}-100(1 \%)$ was added to the cells. The slides were incubated in electrophoresis buffer $(\mathrm{pH} 13)$ for 20 min to produce ssDNA. The solution was incubated in EDTA $(1 \mathrm{mM})$ and $\mathrm{NaOH}(300 \mathrm{mM})$. To identify the possible comet, gel electrophoresis was performed on the ssDNA in the slides at $1.0 \mathrm{~V} / \mathrm{cm}$. After neutralization with trizma buffer, ethidium bromide was added for comet visualization. Finally, comet evaluation was based on the percentage of DNA in the tail. 


\section{Statistical analysis}

The obtained data were studied via analysis of variance using the SPPP statistical software (ver. 19). Additionally, comparisons between means were performed using Duncan. The level of significance was $\mathrm{P} \leq 0.05$. All experiments were replicated three times.

\section{Results and discussion}

\section{Microscopic observations}

Microscopic observations showed that 100 and $400 \mu \mathrm{g} / \mathrm{ml} \mathrm{GO}$ decreased the number of spermatogonial colonies and viable cells compared to control samples. In addition, changes in the morphology of the cells were observed by the formation of intracellular vacuoles. This might be due to the sharp edges of the GO sheets, which can damage cell membranes. These results confirm previous studies claiming that GO can damage adult stem cells (Akhavan et al., 2012; Akhavan et al., 2013; Akhavan, Choobtashani\& Ghaderi, 2012). The detrimental effects of rGO on cells were reported to be less than those of GO. Nevertheless, at a concentration of $400 \mu \mathrm{g} / \mathrm{ml}$, rGO had a negative impact on cell morphology and spermatogonial colony formation (Figure 1).

\section{Figure 1}

\section{Synthesis of GO and rGO:}

A typical AFM image of the GO nanosheets is presented in Figure 2A. The height profile shows thicknesses of $\sim 0.8 \mathrm{~nm}$ for the nanosheets (Figure 2B). According to previous GO studies, the typical thickness of single-layer GO sheets is $\sim 0.8 \mathrm{~nm}$, which is $\sim 0.44 \mathrm{~nm}$ thicker than that of graphene $(\sim 0.36 \mathrm{~nm})$. This could be due to the presence of oxygen-containing functional groups 
on GO, which confirms that single-layer graphene was synthesized (Schniepp et al., 2006; Mc Allister et al., 2007; Akhavan, 2010; Liu\& Seo 2010; Akhavan\& Ghaderi, 2012).

We performed a typical XPS survey spectrum on GO and rGO that showed the available elements on the GO and rGO surfaces. The spectrum was mainly composed of oxygen (O 1s) and carbon $(\mathrm{C} 1 \mathrm{~s})$ peaks (Figure $2 \mathrm{C}$ ). The integrated peak area of $\mathrm{O} 1 \mathrm{~s}$ and $\mathrm{C} 1 \mathrm{~s}$ indicated that the reduction of GO to $\mathrm{rGO}$ decreased the $\mathrm{O} / \mathrm{C}$ ratio from 0.45 to 0.16 . The $\mathrm{N} 1 \mathrm{~s}$ and $\mathrm{S} 2 \mathrm{p}$ core levels indicated that there were traces of nitrogen and sulfur (1.5-0.7\%) in the graphite oxide. Additional insights into the nature of the chemical bonds were obtained by XPS analysis of the core level of GO and rGO (Figure 2D). As shown in Figure 2D, the peak fixed at $285.0 \mathrm{eV}$ was attributed to the $\mathrm{C}-\mathrm{C}$ and $\mathrm{C}=\mathrm{C}$ bonds, and the other deconvoluted peaks located at 286.6, 287.3, 288.3 and $289.3 \mathrm{eV}$ were attributed to oxygen-containing functional groups, including $\mathrm{C}-\mathrm{OH}, \mathrm{C}-$ $\mathrm{O}-\mathrm{C}, \mathrm{C}=\mathrm{O}$, and $\mathrm{O}=\mathrm{C}-\mathrm{OH}$ (Hummers\& Offeman, 1958; Kovtyukhova et al., 1999). The XPS of rGO shows another deconvoluted peak at $285.9 \mathrm{eV}$ that can be attributed to the formation of C$\mathrm{N}$ bonds on the surface of the hydrazine-rGO sheets (Esfandiar, Akhavan\& Irajizad 2011).

Elemental composition analysis was used to compare the oxygen, carbon, hydrogen and nitrogen content of the GO material with the XPS results. The results showed that graphite consisted of $\mathrm{C}(93.7 \%), \mathrm{O}(4.1 \%)$ and $\mathrm{H}(2.2 \%)$, whereas GO contained $\mathrm{C}(37.0 \%), \mathrm{O}(32.8 \%)$, and $\mathrm{H}(30.2 \%)$. Nitrogen was not found in GO. This may be due to the trace availability of nitrogen or the low sensitivity of the elemental composition method.

The carbon structures of the GO and rGO sheets were analyzed using Raman spectroscopy (Figure 2E). According to the results, deoxygenation of GO leads to an increase in the intensity of the $\mathrm{D}$ band $\left(\sim 1355 \mathrm{~cm}^{-1}\right)$ and a decrease in the intensity of the $\mathrm{G}$ band $(\sim 1585$ $\left.\mathrm{cm}^{-1}\right)$. The increase in the ID/IG intensity ratio from 0.92 to 1.19 for GO can be ascribed to a 
decrease in the graphitic domain size and/or an increase in defects due to the formation of $\mathrm{C}-\mathrm{N}$ bonds.

Additionally, inductively coupled plasma mass spectrometry analysis was performed to detect any metal impurities introduced into the graphene material during chemical treatment. High concentrations of $\mathrm{K}$ and $\mathrm{Mn}(<10 \mathrm{ppm})$ and trace $\mathrm{Ni}, \mathrm{Cu}, \mathrm{Fe}$ and $\mathrm{Cr}$ ( > $20 \mathrm{ppb}$ ) were found in GO. The high levels of $\mathrm{K}$ and $\mathrm{Mn}$ in the $\mathrm{GO}$ material may be due to the usage of $\mathrm{KMnO}_{4}$ in the Hummer method (Chng and Pumera 2013; Chua et al., 2014).

\section{Figure 2.}

\section{Survival test of spermatogonia}

The survival test of nanoparticle-treated spermatogonial cells was performed using the MTT assay. As shown in Figure 3, graphene nanoparticles induced a significant level of cell death at high concentrations of 100 and $400 \mu \mathrm{g} / \mathrm{ml}$. This reduction in the cell survival rate could be due to cell membrane damage induced by graphene particles. These results are consistent with previous studies asserting that high concentrations of graphene have negative effects on the survival of cell lines (Akhavan et al., 2012; Akhavan et al., 2013; Akhavan, Choobtashani\& Ghaderi, 2012). It has been observed that the synthesis of graphene by transition-metal dichalcogenides (TMDs) has dose-dependent cell toxicity on A549 cells. The viability of A549 cells was decreased by $31.8 \%$ after the addition of $400 \mu \mathrm{g} / \mathrm{ml} \mathrm{WSe}_{2}$ (Teo et al, 2014). This treatment was less hazardous than that of our synthesized graphene, which exhibited $58 \%$ cell viability at high concentrations (400 $\mu \mathrm{g} / \mathrm{ml})$, although SSCs are much more sensitive than A549 cells. Halogenated graphene was not compatible with A549 viability, as cells treated with chlorine- (TRGO-Cl), bromine- 
(TRGO-Br) and iodine-doped graphene (TRGO-I) had lower viability ratios than that observed by Teo et al. (2014).

\section{ROS assay}

A significantly increased level of ROS was measured in cells treated with GO at final concentrations of 100 and $400 \mu \mathrm{g} / \mathrm{ml}$. Changes in the ROS content were not significant at low concentrations (Figure 4). These results are in line with the results of other studies demonstrating GO induced oxidative stress in the cells (Akhavan, Ghaderi\& Akhavan, 2012; Akhavan et al., 2013; Akhavan, Choobtashani\& Ghaderi, 2012). However, the treatment of rGO at a high concentration of $400 \mu \mathrm{g} / \mathrm{ml}$ indicated a significant difference in ROS production in comparison with the control $(\mathrm{P} \leq 0.05)$. These effects may be explained by the penetration of sharp-edged graphene nanoparticles into biological membranes, impairing intracellular organelles and increasing the production of free radicals by the harmed cells.

\section{Figure 3,4.}

\section{DNA fragmentation}

To study the genotoxicity of graphene nanoparticles on SSCs, the DNA fragmentation ratios of GO and rGO in terms of the DNA percentage were calculated using the comet assay. As shown

in figure 5, there is a direct relationship between the levels of DNA fragmentation and the GO concentration, where high levels of DNA damage were observed by increasing the nanoparticle dose. The highest genotoxicity was detected when the SSCs were treated with $400 \mu \mathrm{g} / \mathrm{ml}$ GO. DNA fragmentation at a low concentration of graphene can be attributed to the penetration of GO into cells and interacting with nuclei. Such penetration can partially damage the cell membrane, resulting in slight cell destruction. These results contradict those of a previous study 
(Liu et al., 2009) that claimed that nanoparticles do not impair DNA. However, as described by Yun et al. (2011), this inconsistency may be related to the cell types used. In addition, the results of the present study show that the toxicity of graphene decreased by reducing this nanomaterial. This is in line with the results of recent studies reporting that the toxicity of the graphene material may be influenced by its physicochemical properties, such as surface functional groups and structural defects (Chng et al. 2013). However, more recent studies claimed that highly hydrogenated graphene is more cytotoxic than GO (Chng, Sofer and Pumer 2014). As reported by Chng et al. (2013), the use of different chemical treatments to synthesize graphene introduces impurities that may affect its toxicity. In the present study, the researchers employed the Hummer method, which mainly introduces $\mathrm{Mn}$ and $\mathrm{K}$ to the graphene material. Acid treatment decreased the metal content of graphene; however, a further evaluation of the toxicity risk of $\mathrm{Mn}$ and $\mathrm{K}$ on the graphene material is necessary.

\section{Figure 5}

\section{Membrane integrity}

Loss of membrane integrity is considered to be a sign that a nanomaterial is cytotoxic. Here, this problem was studied using acridine orange staining. As shown in figure 6, green staining represents viable SSCs and orange staining represents apoptotic SSCs. The results showed that high concentrations of GO caused membrane damage following apoptosis. The morphological changes of SSCs treated with GO were also observed by acridine orange staining. In figure 6C, both green and orange cells were observed, but the number of apoptotic cells in the GO-treated sample is higher than rGO treated and untreated cells in Figure 6A and 6B. Moreover, cells

treated with GO had morphological changes, such as a decreased cell volume, cell shrinkage and 
chromatin condensation. Previously, a direct relationship between the ROS level and apoptosis was described (REFs). This study reported an enhanced ROS level in the presence of high concentrations of the graphene nanomaterial. At high concentrations, graphene nanoparticles tended to aggregate, forming clusters and sticking to the cell membrane. This observation could explain the loss of cell membrane integrity following ROS-induced apoptosis. Similarly to graphene, which may be graphene oxide under these conditions, negatively charged carboxyl groups on the GO surface may allow it to enter the cell by increasing its solubility and decreasing material aggregation.

\section{Fig 6.}

\section{Conclusion}

In this study, the cyto- and genotoxicity of GO and rGO on SSCs were explored for the first time. According to the results, high concentrations (100 and $400 \mu \mathrm{g} / \mathrm{ml}$ ) of GO and rGO induced toxicity on SSCs after $24 \mathrm{~h}$ of exposure. The present study asserts that SSCs, cells that are responsible for producing germ cells that transfer genetic material to offspring, are very sensitive to toxicants, such as nanoparticles. However, graphene nanomaterials are increasingly utilized in biomedicine and industry.

\section{Acknowledgements}

The authors would like to thank the Iran National Science Foundation (INSF) for financial support of the work. Many thanks to the National Institute of Genetic Engineering and Biotechnology and the Sharif University of Technology for the facilities used to conduct this study. 


\section{References}

Akhavan O. (2010) The effect of heat treatment on formation of graphene thin films from graphene oxide nanosheets. Carbon 48, 509-519.

Akhavan, O., Ghaderi, E., Akhavan A. (2012) Size-dependent genotoxicity of graphene nanoplatelets in human stem cells. Biomaterials. 33, 8017-8025.

Akhavan, O., Ghaderi, E., Emamy, H., Akhavan F. (2013) Genotoxicity of graphene nanoribbons in human mesenchymal stem cells. C arbon 54, 419-431.

Akhavan, O., Choobtashani, M., Ghaderi, E. (2012) Protein Degradation and RNA Efflux of Viruses Photocatalyzed by Graphene-Tungsten Oxide Composite Under Visible Light Irradiation. J. Phys. Chem. C 116, 9653-9659.

Akhavan O, Ghaderi E, (2010) Toxicity of graphene and graphene oxide nanowalls against bacteria. ACS Nano 4(10), 5731-5736.

Akhavan O, Ghaderi E, Akhavan A, (2012) Size-dependent genotoxicity of graphene nanoplatelets in human stem cells. Biomaterials 33(32), 8017-8025.

Akhavan, O.; Ghaderi, E.; Aghayee, S.; Fereydooni, Y.; Talebi, A. (2012) The Use of a GlucoseReduced Graphene Oxide Suspension for Photothermal Cancer Therapy. J. Mater. Chem. 22, 13773-13781.

Akhavan, O., Ghaderi, E., Emamy, H. (2012) Nontoxic Concentrations of PEGylated Graphene Nanoribbons for Selective Cancer Cell Imaging and Photothermal Therapy. J. Mater. Chem. 22, 20626-20633.

Akhavan O, Ghaderi E. (2012) Escherichia coli bacteria reduce graphene oxide to bactericidal graphene in a self-limiting manner. Carbon 50, 1853-1860. 
Artiles MS, Rout CS, Fisher TS, (2011) Graphene-based hybrid materials and devices for biosensing. Adv Drug Deliv Rev 63(14-15), 1352-1360.

Bao H, Pan Y, Ping Y, Sahoo NG, Wu T, Li L, Li J, Gan LH, (2011) Chitosan-functionalized graphene oxide as a nanocarrier for drug and gene delivery. Small 7(11),1569-1578.

Calizo I, Balandin AA, Bao W, Miao F, Lau CN. (2007) Temperature dependence of the Raman spectra of graphene and graphene multilayers. Nano Lett 7, 2645-2649.

Chang Y, Yang S-T, Liu J-H, Dong E, Wang Y, Cao A, Liu Y, Wang H, (2010) In vitro toxicity evaluation of graphene oxide on A549 cells. Toxicol Lett 200(3), 201-210.

Chng, E. L. K. and Pumera, M. (2013), The Toxicity of Graphene Oxides: Dependence on the Oxidative Methods Used. Chem. Eur. J., 19: 8227-8235.

Chng, E. L. K., Sofer, Z. and Pumera, M. (2014), Cytotoxicity Profile of Highly Hydrogenated Graphene. Chem. Eur. J., 20: 6366-6373.

Chua, C. K., Ambrosi, A., Sofer, Z., Macková, A., Havránek, V., Tomandl, I. and Pumera, M. (2014), Chemical Preparation of Graphene Materials Results in Extensive Unintentional Doping with Heteroatoms and Metals. Chem. Eur. J., 20: 15760-15767.

Esfandiar A, Akhavan O, Irajizad A. (2011) Melatonin as a powerful bio-antioxidant for reduction of graphene oxide. J Mater Chem 21, 10907-10914.

Feng L, Zhang S, Liu Z, (2011) Graphene based gene transfection. Nanoscale 3(3):1252-1257.

Feng, L. \& Liu, Z. (2011) Graphene in biomedicine: opportunities and challenges. Nanomedicine $6,317-324$

Graf D, Molitor F, Ensslin K, Stampfer C, Jungen A, Hierold C, Wirtz L. (2007) Spatially resolved Raman spectroscopy of single- and few-layer graphene. Nano Lett 7, 238-242. 
Guan, K., Wolf, F., Becker, A., Engel, W., Nayernia, K., Hasenfuss, G. (2009) Isolation and cultivation of stem cells from adult mouse testes. Nat. Protoc. 4, 143-154.

Hashemi, E., Akhavan, O., Shamsara, M., Rahighi, R., Esfandiar, A., Tayefeh, A.R. (2014) Cyto and genotoxicity of graphene oxide and reduced graphene oxide sheets on spermatozoa. RSC Advances, 4, 27213-27223.

Heidarimoghadam, R., Akhavan, O., Ghaderi, E., Hashemi, E., Mortazavi, S. S., Farmany, A. (2016) Graphene oxide for rapid determination of testosterone in the presence of cetyltrimethylammonium bromide in urine and blood plasma of athletes, Mater. Sci. and Eng. C $61,246-250$

Hummers WS, Offeman RE. (1958) Preparation of graphite oxide. J Am Chem Soc 80,13391339.

Kim KS, Zhao Y, Jang H, Lee SY, Kim JM, Kim KS, Ahn JH, Kim P, Choi JY, Hong BH. (2009) Large-scale pattern growth of graphene films for stretchable transparent electrodes. Nature 457, 706-710.

Jain K (2010) Advances in the field of nanooncology. BMC Medicine 8, 83.

Kovtyukhova NI, Ollivier PJ, Martin BR, Mallouk TE, Chizhik SA, Buzaneva EV, Gorchinskiy AD. (1999) Layer-by-layer assembly of ultrathin composite films from micron-sized graphite oxide sheets and polycations. Chem Mater 11, 771-778.

Li, D., Müller, M. B., Gilje, S., Kaner, R. B., Wallace, G. G. (2008) Processable Aqueous Dispersions of Graphene Nanosheets. Nat. Nanotechnol. 3, 101-105. 
Li Y, Liu Y, Fu Y, Wei T, Le Guyader L, Gao G, Liu R-S, Chang Y-Z, Chen C, (2012) The triggering of apoptosis in macrophages by pristine graphene through the MAPK and TGF-beta signaling pathways. Biomaterials 33(2), 402-411.

Liu F, Seo TS. (2010) A controllable self-assembly method for large-scale synthesis of graphene sponges and free-standing graphene films. Adv Funct Mater 20,1930-1936.

Liu L, Ryu S, Tomasik MR, Stolyarova E, Jung N, Hybertsen MS, Steigerwald ML, Brus LE, Flynn GW. (2008) Graphene oxidation: thickness-dependent etching and strong chemical doping. Nano Lett 8,1965-1970.

Liu KK, Wang CC, Cheng CL, Chao JI. (2009) Endocytic carboxylated nanodiamond for the labeling and tracking of cell division and differentiation in cancer and stem cells. Biomaterials. $30(26), 4249-59$

Malard LM, Pimenta MA, Dresselhaus G, Dresselhaus MS. (2009) Raman spectroscopy in graphene. Phys Rep 473, 51-87.

Maynard AD, Aitken RJ, Butz T, Colvin V, Donaldson K, et al. (2006) Safe handling of nanotechnology. Nature 444, 267-269.

Maynard AD. (2011) Don’t define nanomaterials. Nature. 475, 31.

Mc Allister MJ, Li JL, Adamson DH, Schniepp HC, Abdala AA, Liu J, Herrera-Alonso M, Milius DL, Car R, Prud'homme RK, Aksay IA. (2007) Single sheet functionalized graphene by oxidation and thermal expansion of graphite. Chem Mater 19, 4396-4404.

Odorico, J. S., Kaufman, D. S., Thomson, J. A., (2011) Multilineage differentiation from human embryonic stem cell lines. Stem Cells. 19(3),193-204. 
Sanchez VC, Jachak A, Hurt RH, Kane AB, (2012) Biological interactions of graphene-family nanomaterials: an interdisciplinary review. Chem Res Toxicol 25(1),15-34.

Sasidharan A, Panchakarla LS, Chandran P, Menon D, Nair S, Rao CNR, Koyakutty M, (2011) Differential nano-bio interactions and toxicity effects of pristine versus functionalized graphene. Nanoscale 3(6), 2461-2464.

Shen J, Zhu Y, Yang X, Li C, (2012) Graphene quantum dots: emergent nanolights for bioimaging, sensors, catalysis and photovoltaic devices. Chem Commun 48(31), 3686-3699.

Schniepp HC, Li JL, McAllister MJ, Sai H, Herrera-Alonso M, Adamson DH, Prud'homme RK, Car R, Saville DA, Aksay IA. (2006) Functionalized single graphene sheets derived from splitting graphite oxide. J Phys Chem B 110, 8535-8539.

Sun XM, Liu Z, Welsher K, et al. (2008) Nano-graphene oxide for cellular imaging and drug delivery. Nano Res. 1(3), 203-212.

Teo, W. Z., Chng, E. L. K., Sofer Z., and Pumera, M. (2014) Cytotoxicity of halogenated graphemes, Nanoscale 6, 1173-1180.

Teo, W. Z., Chng, E. L. K., Sofer, Z. and Pumera, M. (2014), Cytotoxicity of Exfoliated Transition-Metal Dichalcogenides $\left(\mathrm{MoS}_{2}, \mathrm{WS}_{2}\right.$, and $\left.\mathrm{WSe}_{2}\right)$ is Lower Than That of Graphene and its Analogues. Chem. Eur. J., 20: 9627-9632.

Tice RR, Agurell E, Anderson D, Burlinson B, Hartmann A, Kobayashi H, Miyamae Y, Rojas E, Ryu JC, Sasaki YF., (2000) Single cell gel/comet assay: guidelines for in vitro and in vivo genetic toxicology testing. Environ Mol Mutagen. 35(3), 206-21.

Yang, K., Zhang, S., Zhang, G., Sun, X., Lee, S. T., Liu, Z. (2010) Graphene in Mice: Ultrahigh In Vivo Tumor Uptake and Efficient Photothermal Therapy. Nano Lett. 10, 3318-3323. 
Yuan J, Gao H, Sui J, Duan H, Chen WN, Ching CB, (2012) Cytotoxicity evaluation of oxidized single-walled carbon nanotubes and graphene oxide on human hepatoma HepG2 cells: an iTRAQ-coupled 2D LC-MS/MSproteome analysis. Toxicol Sci 126(1),149-161.

Yun X., Wei X., Lin Z., Eiji O., Saber H., and Liming D. (2011) DNA Damage in Embryonic Stem Cells Caused by Nanodiamonds, ACS Nano, 5 (3), pp 2376-2384

Yue H, Wei W, Yue Z, Wang B, Luo N, Gao Y, Ma D, Ma G, Su Z, (2012) The role of the lateral dimension of graphene oxide in the regulation of cellular responses. Biomaterials 33(16), 4013-4021.

Zhang L, Xia J, Zhao Q, Liu L, Zhang Z, (2010) Functional graphene oxide as a nanocarrier for controlled loading and targeted delivery of mixed anticancer drugs. Small 6(4), 537-544.

Yang X, Wang Y, Huang X, Ma Y, Huang Y, Yang R, Duan H, Chen Y, (2011) Multifunctionalized graphene oxide based anticancer drug-carrier with dual-targeting function and $\mathrm{pH}$ sensitivity. J Mater Chem 21(10), 3448-3454.

Zhang L, Lu Z, Zhao Q, Huang J, Shen H, Zhang Z, (2011) Enhanced chemotherapy efficacy by sequential delivery of siRNA and anticancer drugs using PEI-grafted graphene oxide. Small 7(4), $460-464$.

Zhang Y, Ali SF, Dervishi E, Xu Y, Li Z, Casciano D, Biris AS, (2010) Cytotoxicity effects of graphene and single-wall carbon nanotubes in neural phaeochromocytoma-derived PC12 cells. ACS Nano 4(6), 3181-3186.

Zhu J, Liao L, Bian X, Kong J, Yang P, Liu B, (2012) pH-controlled delivery of doxorubicin to cancer cells, based on small mesoporous carbon nanospheres. Small 8(17), 2715-2720. 
Zhu S, Zhang J, Qiao C, Tang S, Li Y, Yuan W, Li B, Tian L, Liu F, Hu R, et al. (2011) Strongly green-photoluminescent graphene quantum dots for bioimaging applications. Chem Commun 47(24), 6858-6860. 


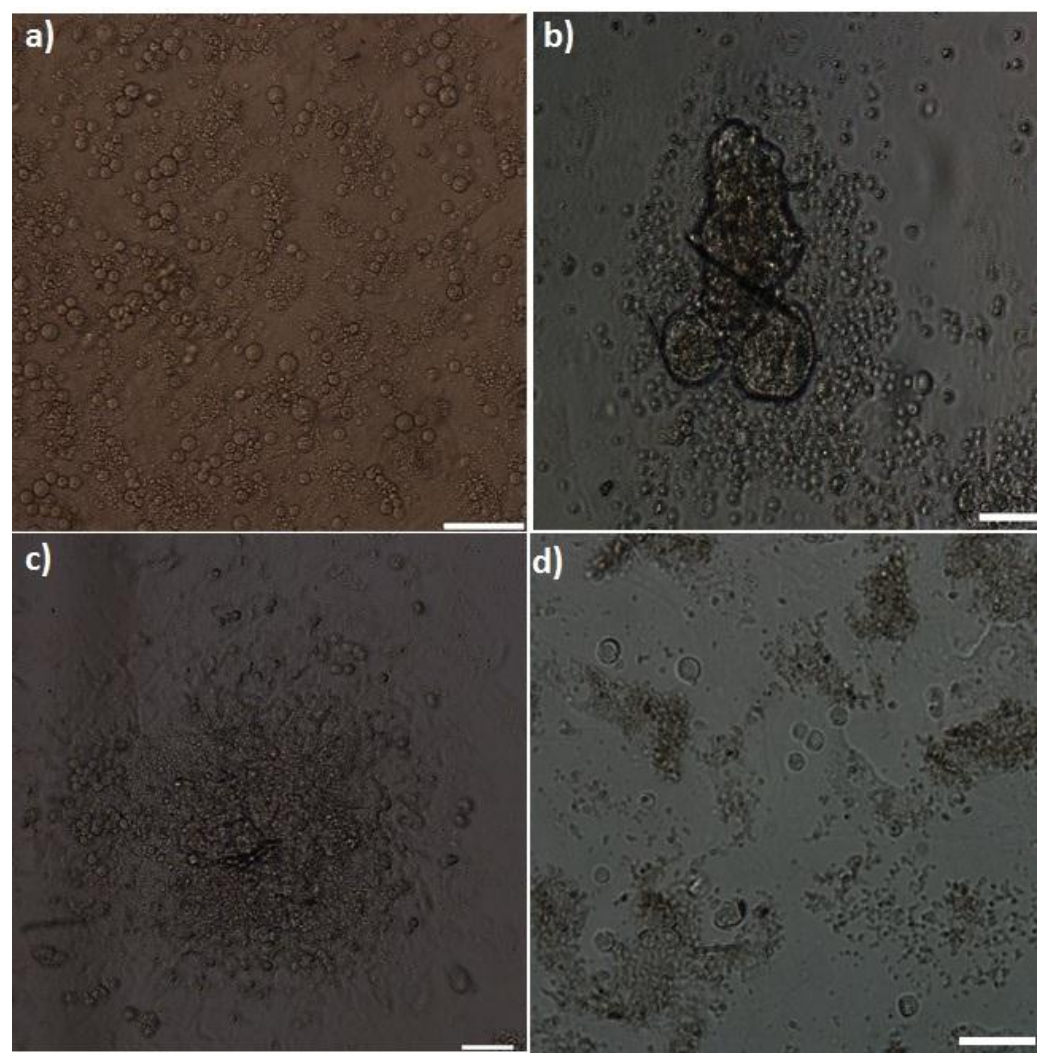

Figure 1. a) Coculture of SSCs on mouse embryonic fibroblasts; b) SSCs colonies on the surface of fibroblasts control group; c) SSCs after treatment with rGO; d) SSCs after treatment with GO (the scale bar shows $50 \mu \mathrm{m}$ ). 


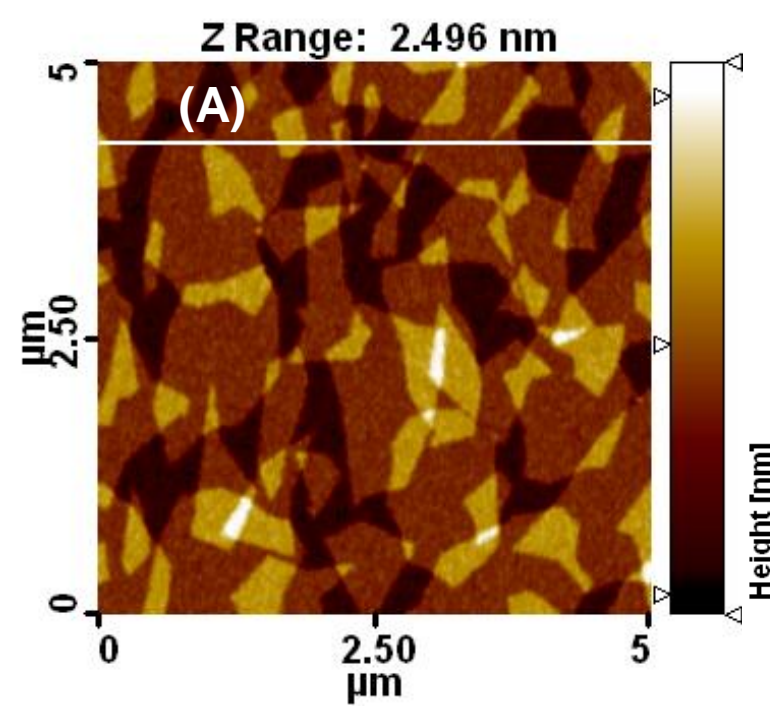

(B)
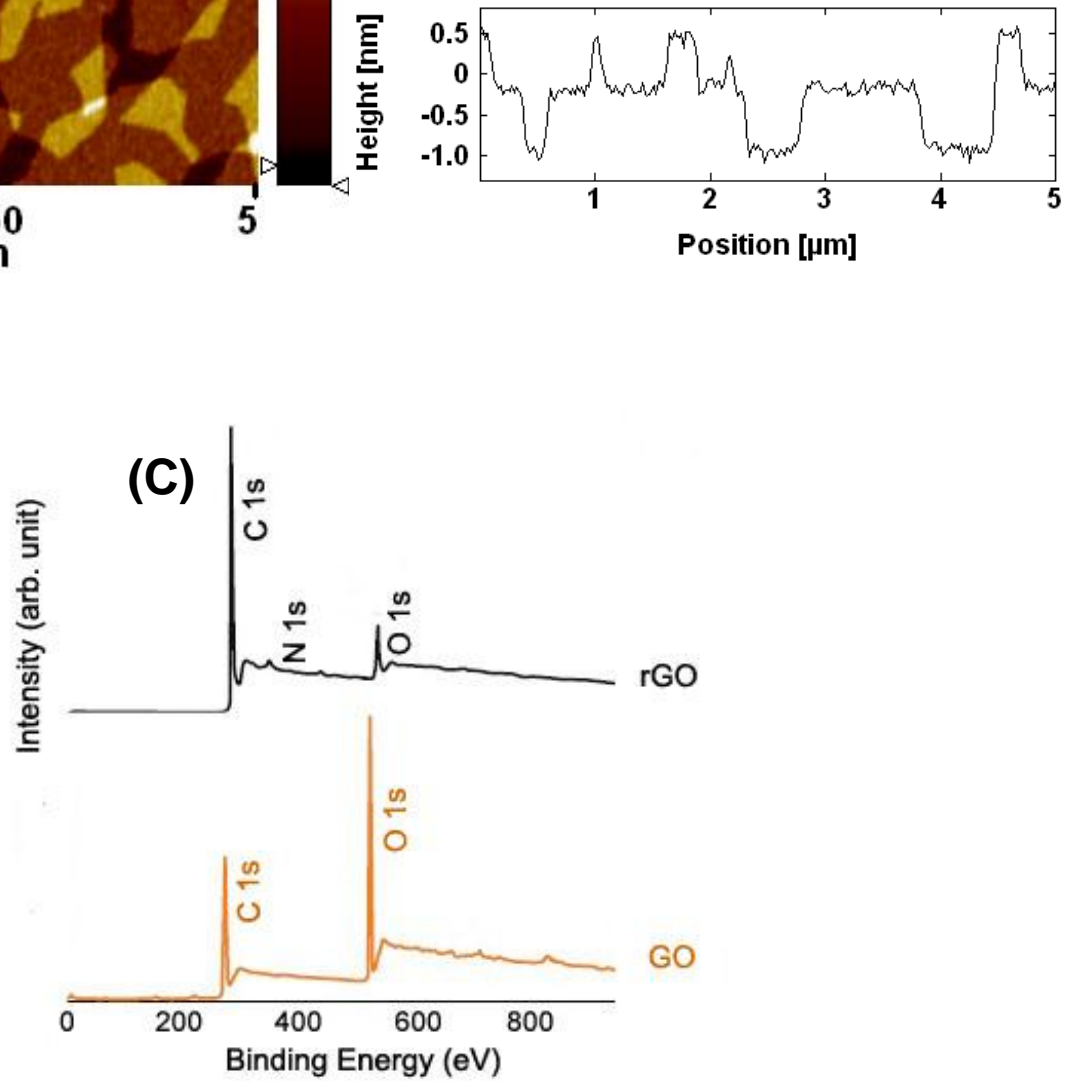

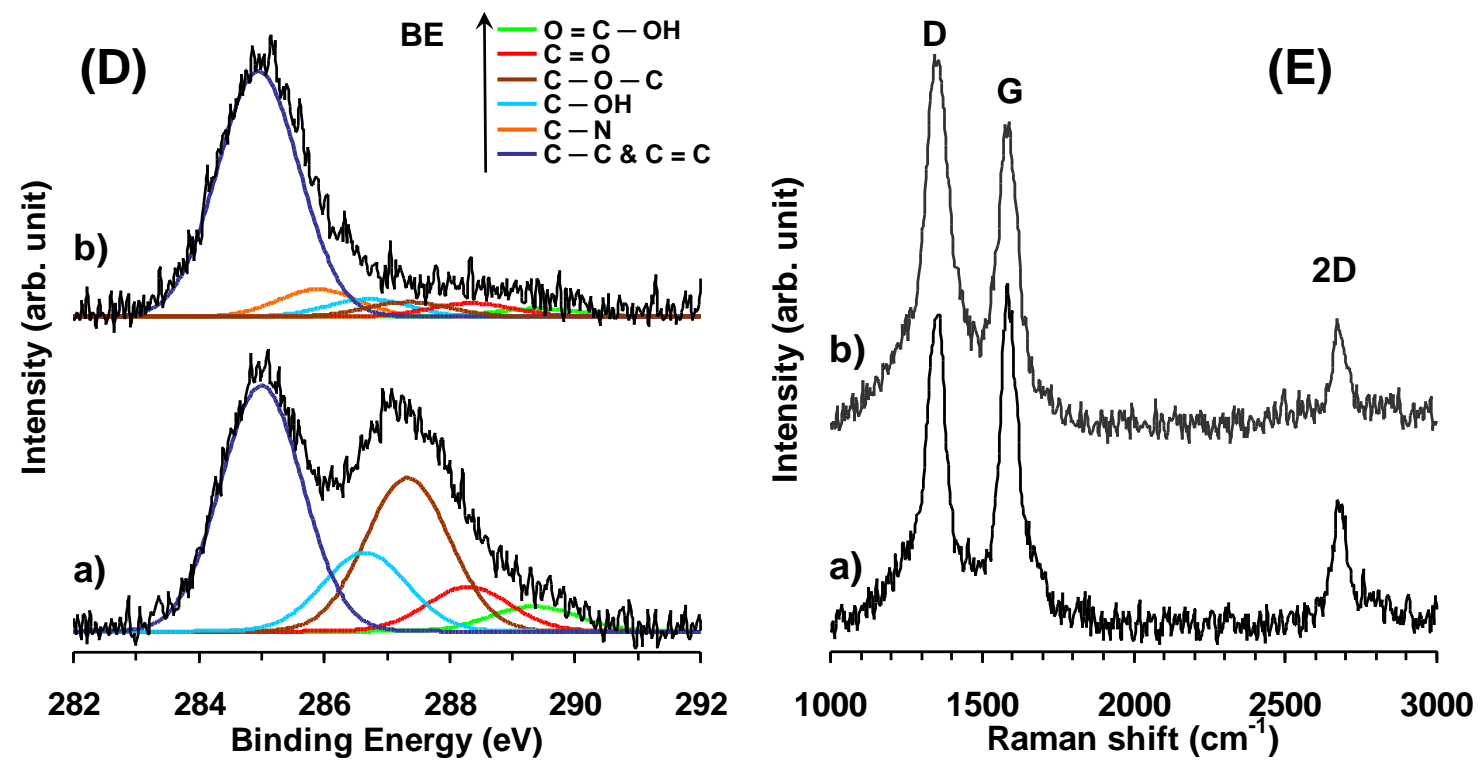

Figure 2. A) AFM image of GO sheets; B) height profile of the sheets marked by a line in (A); C) XPS survey spectra of GO and rGO; D) XPS and E) Raman spectra of a) GO and b) rGO sheets. 


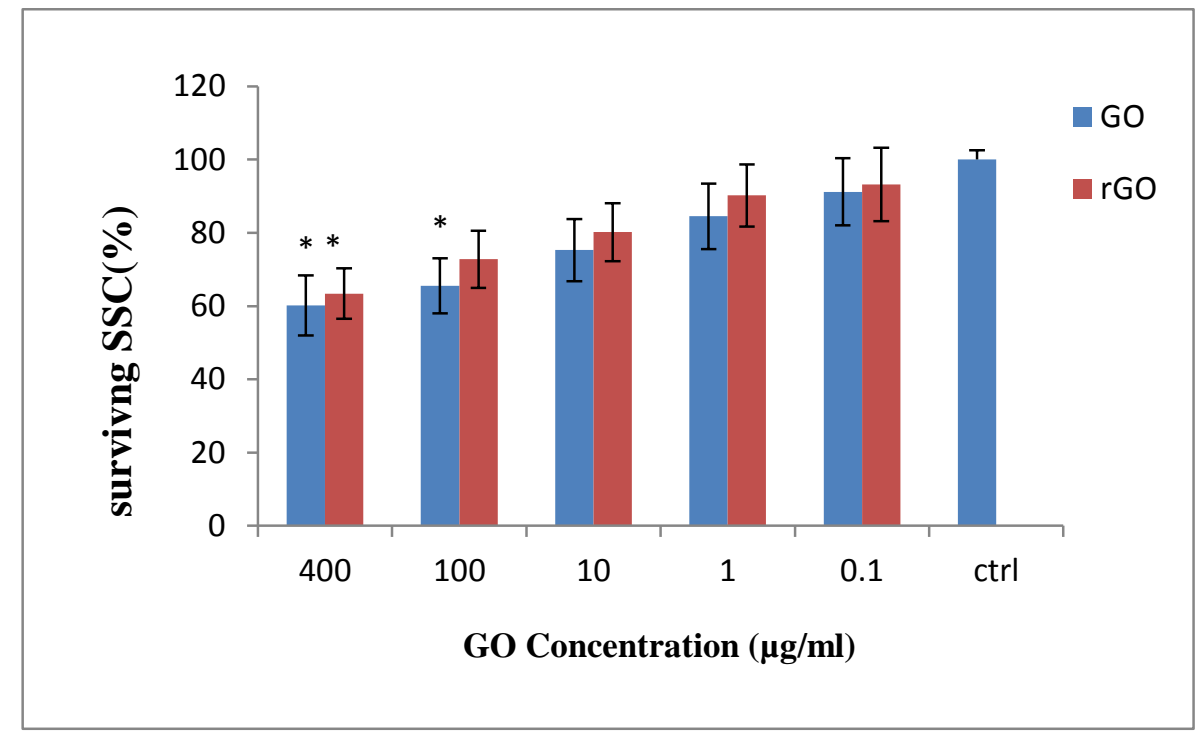

Figure 3. Plotting survival spermatogonial cells test treated with GO and rGO. The graphene at the concentrations of 100 and $400 \mu \mathrm{g} / \mathrm{ml}$ showed a significant effect on decreasing cell number $(\mathrm{P} \leq 0.05)$. Surviving cells were measured using MTT assay. Error bars were calculated based on standard deviations of three replications per group $(\mathrm{N}=3)$. 


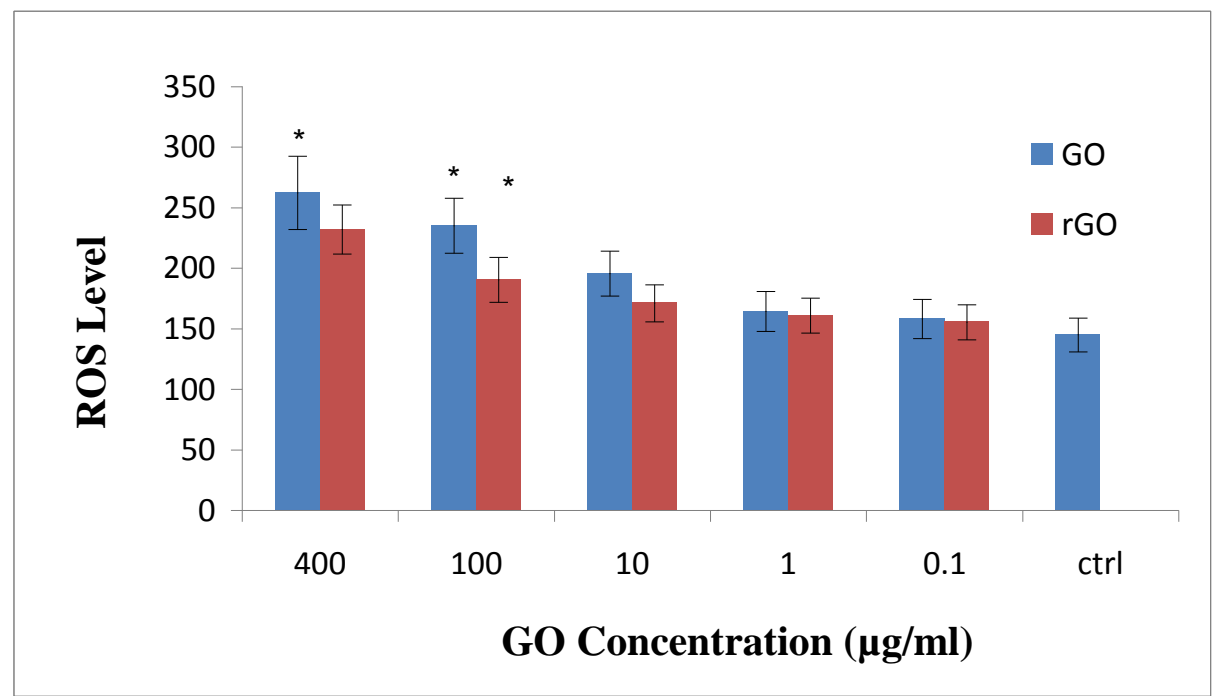

Figure 4. Plotting the measurement of free radicals. The results show that the graphenes at the concentrations of 100 and $400 \mu \mathrm{g} / \mathrm{ml}$ had a significant effect on increasing the ROS level $(\mathrm{P} \leq 0.05)$. Free radicals were measured using DCFH assay. Error bars were calculated based on standard deviations of three replications per group $(\mathrm{N}=3)$. 


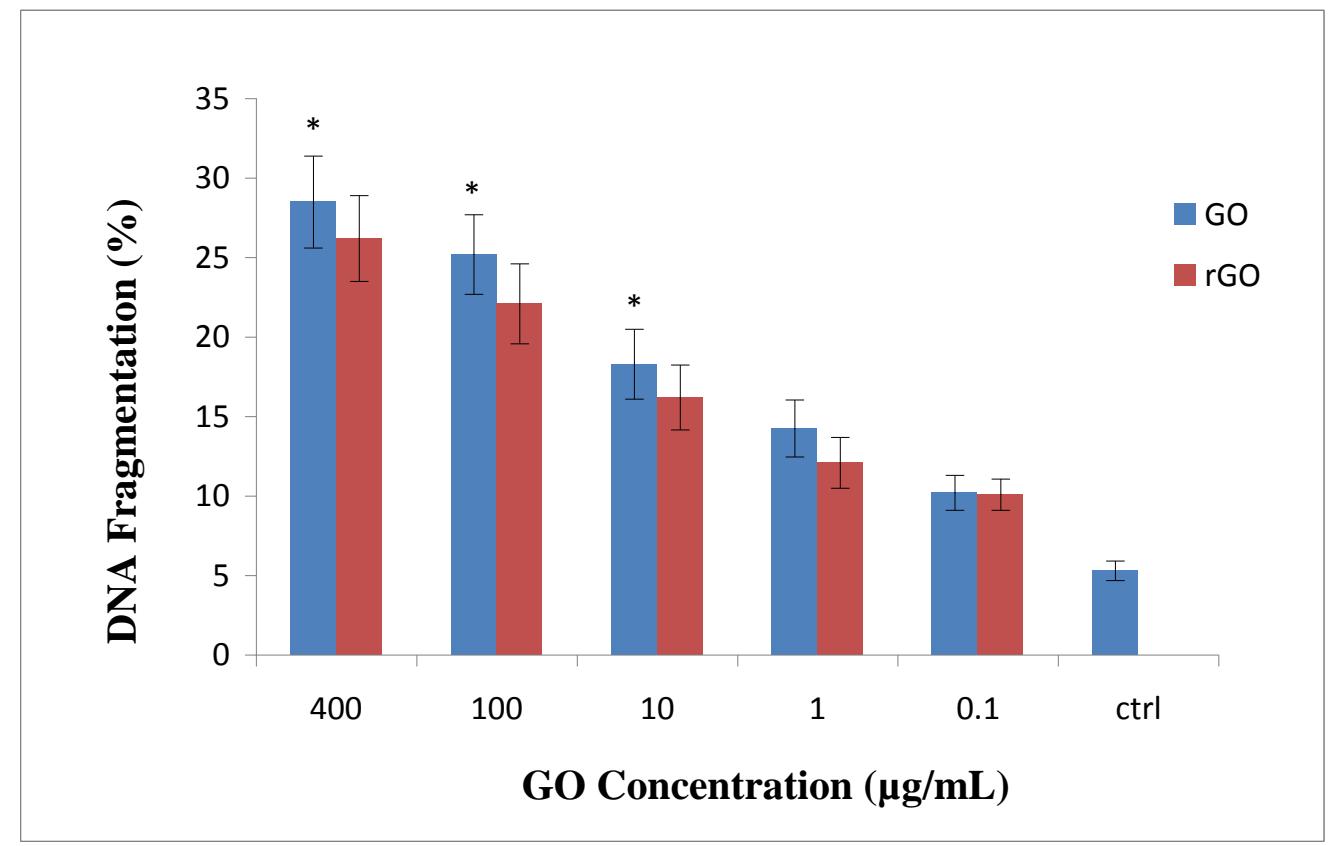

Figure 5. DNA fragmentation percentage at different concentrations of GO and rGO. DNA fragmentation was measured using comet assay. Error bars were calculated based on standard deviations of three replications per group $(\mathrm{N}=3)$. 

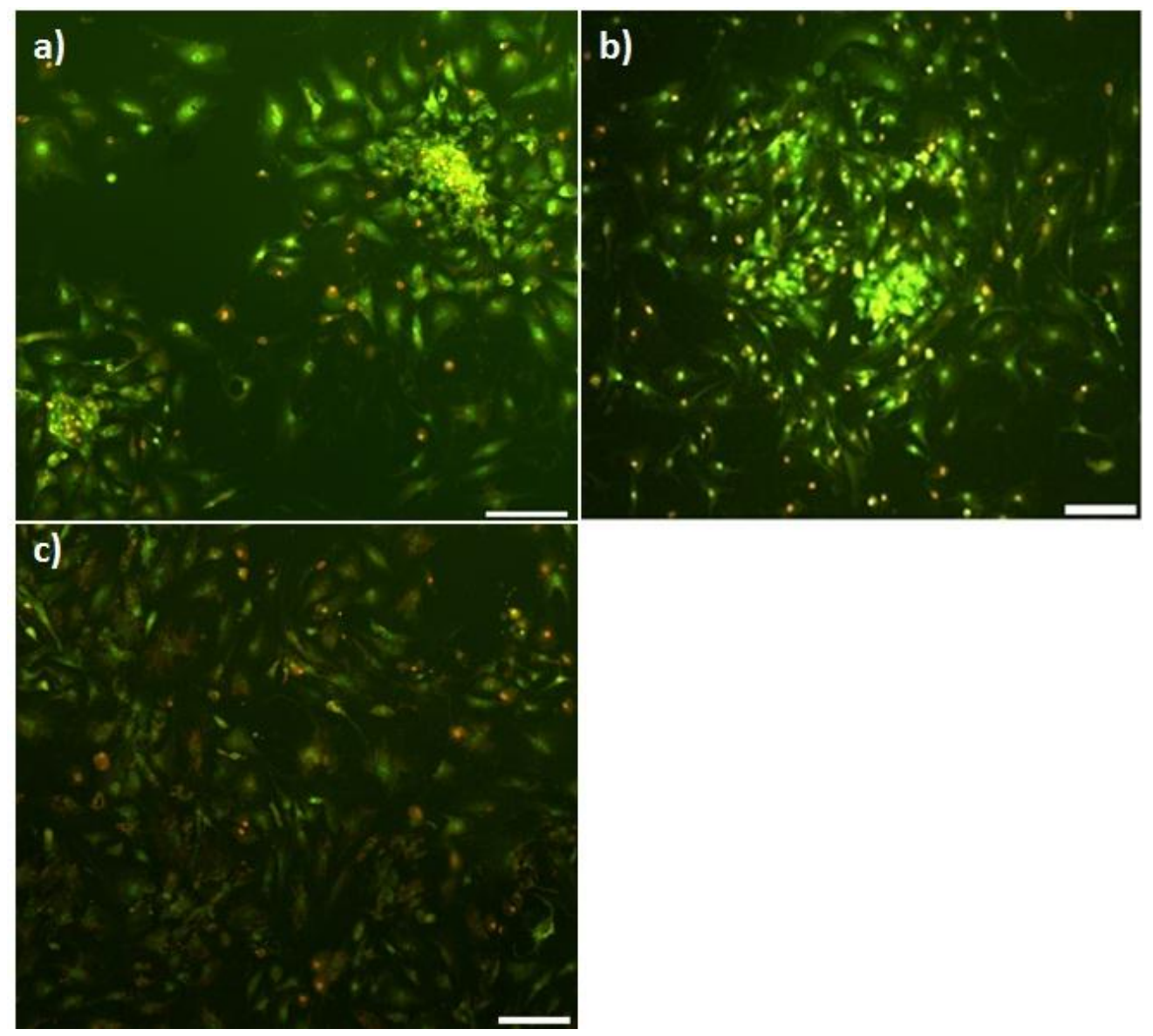

Fig 6. Fluorescence microscopic images of the cells stained by alcidine orange. a) control, b) rGO- and c) GO group with acridine orange staining (the scale bar shows $50 \mu \mathrm{m}$ ). Green staining represents viable SSCs, whereas reddish or orange staining represents late apoptotic cells. 